\title{
Evolution and Development of Contract Farming in Zimbabwe: A Reflection for Agribusiness
}

\author{
Kundai Tutuka Parirenyatwa \\ Master of Development Finance (MDevF), University of Stellenbosch, South Africa. \\ kundaiparry@yahoo.com \\ Stephen Mago \\ Senior Lecturer, University of Fort Hare, P. Bag X1314,Alice,5700, South Africa. \\ stepmago@gmail.com
}

\section{Doi:10.5901/mjss.2014.v5n20p237}

\begin{abstract}
Agriculture in developing countries is characterised by low productivity and underutilisation of arable land. Southern African countries such as Zimbabwe and South Africa have a long history of excluding black farmers in the commercial farming sector. Prior to independence, colonial policies favoured the white minority over the black majority, thereby creating large numbers of peasant farmers. Literature argues that contract farming can play a vital role in raising the agricultural productivity of peasant farmers. In contract farming, an agribusiness firm lends inputs such as fertilizer, seeds and pesticides to a farmer in return for the crop grown. This paper examines the Tian Ze Tobacco Company (TZTC) contract farming scheme in Zimbabwe as a "vehicle" to promote a new breed of emerging black commercial farmers in Southern Africa. The results of this study confirm that contract farming has a potential to boost productivity in Zimbabwe's farming sector and empower the emerging black farmers.
\end{abstract}

Keywords: Contract farming, emerging black farmer, agricultural finance, Land Reform, Zimbabwe.

\section{Introduction}

Agriculture has evolved exponentially since the advent of globalisation and industrialisation. The global demands for different varieties of food have been exacerbated by the worldwide need for the year-round supply of the same food (Kirsten \& Sartorius, 2002). Prior to independence, foreign owned plantations in South America and Asia produced agricultural goods the world demanded. The end of colonisation saw many of these plantations break up as the foreign agribusinesses were subject to domestic political uncertainty and nationalisation (Baumann, 2000). To meet global demand, agribusiness firms could no longer afford to operate autonomously. Nowadays, the survival of an agribusiness firm is dependent on its successful vertical integration into food supply chains (Kirsten \& Sartorius, 2002).

One practice that agribusiness firms have adopted to successfully integrate themselves into the food supply chain is contract farming. It involves the lending of inputs such as fertilizer, credit and seeds to a farmer (Anim et al. 2008; Bellemare 2010, Prowse, 2012; Shepherd, 2013; FAO, 2013; Pritchard and Connell, 2011 and Rural Learning Centre, 2014). According to Kirsten and Sartorius (2002), contract farming involves the agreement between a producer and the integrator (usually an agribusiness firm). Costales and Catelo (2008) further add that the binding agreement should specify remuneration for work done, price, quality, quantity, conditions of production and delivery requirements.

As an organisational structure in agriculture, contract farming has a long history dating back to the $20^{\text {th }}$ century. Contract farming arrangements were used to secure sugar and cotton in the United States and had spread to Western Europe by the late $20^{\text {th }}$ century (Kirsten \& Sartorius, 2002). Given its historic success, contract farming has been in existence for many years and has become a standard feature of commercial agricultural production (Shoja Rani, 2007) in developed countries.

In contrast, agriculture in developing countries especially in Africa, is characterised by low productivity and underutilisation of arable land. The role which contract farming can play in raising agricultural productivity of the generally rural population has received considerable attention. On the one hand, contract farming in the African context is seen as a mechanism to alleviate poverty because it has potential to raise the income of the rural farmers (Warning \& Key, 2002). Warning \& Key (2002) argue that some studies have criticised contract farming because of its exploitative nature; a 
perception created by the large number of rural farmers recorded as having been forced into unfavourable contract terms. Southern African countries such as Zimbabwe and South Africa have a long history of excluding black farmers from the commercial farming sector (Sartorius \& Kirsten, 2007). Prior to these countries gaining democracy, the "colonial policies" at the time favoured the white minority over the black majority thereby limiting the majority to very few economic prospects. In Southern African countries such as Zimbabwe and South Africa, the legacy of racially based exclusion in commercial agriculture, which was common practice during colonialism, largely remains unchanged years after independence, and the emergence of new black commercial farmers has been limited. Unlike in other developing countries, the average black farmer has struggled to make the transition from subsistence to market-driven commercial farming (Pandit et al. 2009). Subsistence farmers (the majority of whom are black) typically lack capital and the technical expertise required to commercialise their farming activities by cultivating high yield cash crops (Pandit et al. 2009).

\section{Land Reform}

According to the International Finance Corporation (IFC) (2010), Africa has lagged behind the rest of the world in terms of agricultural productivity, with many traditional export crops (tobacco, wheat, palm oil) losing their international competitiveness over the previous 30 years. This is supported by Shaw (2003) who used the example of Zimbabwe and stated that its labour intensive commercial farms were not efficient by North American standards. Further, low agricultural productivity has been exacerbated by climate change, lack of capital, low capacity, weak infrastructure and poor governance (IFC, 2010).

Commentators such as de Villiers (2008) argue that it will take decades, and possibly generations, to rectify the historical question of land reform. He also highlights that land reform and the need to move the majority of peasant farmers in communal lands to arable productive farms is not limited to Africa. Countries such as Australia, Brazil, Chile, Mexico and India have also been unable to implement successful land reform programmes. Bernstein et al.(2008) of the Centre for Development and Enterprise (CDE), a South African market orientated public policy research organisation, argues that almost all state-led land reform programmes have been largely unsuccessful. Perhaps, the most widely discussed and analysed land reform programme is that of Zimbabwe. Some studies have emphasised the political controversy that surrounded land reform over the last decade. This is again supported by Shaw (2003) who argues that land reform in Zimbabwe has been 'cynically motivated' with the wholesale expropriation of white farms. Rather than continue with the controversial debate, this research project will focus on the events that have led to the current agrarian landscape in Zimbabwe.

\section{Background to the Land Reform in Zimbabwe}

Zimbabwe gained independence in 1980. At the time, the country had inherited a racially unequal agricultural system. Zimbabwe's total land area is 39 million hectares, with approximately 33 million hectares allocated to agriculture and the balance to national parks and urban settlement (Waeterloos \& Rutherford, 2004). Shaw, (2003) notes that white farmers, who constituted less than $1 \%$ of the population in 1980 , owned $47 \%$ of the most productive agricultural land (15.5 million hectares). Since then, the country has had two phases of land reform and resettlement. The first phase, which began immediately after independence under the banner of the Lancaster House Constitution, was based on a willing buyerwilling seller principle. Under this constitution, farmers were protected from compulsory acquisition from 1980 to 1990. The Land Acquisition Act of 1992 provided the government with the machinery to redistribute land by introducing a land tax and allowing for the compulsory purchase of land. However, the government's plan to implement the Land Acquisition Act of 1992 was stalled by the country's adoption of a macroeconomic structural adjustment programme. By 1997, the first phase of the land reform programme had seen the government acquire approximately 3.5 million hectares of land for resettlement (Waeterloos \& Rutherford, 2004).

In 2000, the government adopted the Fast Track Land Reform Programme (FTLRP), which provided for the compulsory acquisition of five million hectares of land targeted for redistribution. At the time, Zimbabwe was the largest producer of tobacco in Africa. However, as Richardson (2004) cited in Zikhali (2010) states, the FTLRP was accompanied by a $30 \%$ decrease in the country's agricultural output by 2004 . Following the completion of FTLRP, the two phases of land reform had seen a total 9.5 million hectares of land being acquired from the 15.5 million hectares owned by white farmers (Waeterloos \& Rutherford, 2004).

The tenure arrangement within the FTLRP has seen the development of two models available to the beneficiaries of land reform. Model A1 ( $3-15$ hectares) aims to allocate land to congested subsistence farmers mainly in the communal areas. These farmers grow crops mainly for self-consumption, and may at times, have a small surplus to sell 
to the market. Model A2 (20 - 20,000 hectares) is aimed at allocating land to any Zimbabwean for commercial purposes should he or she be able to prove their farming experience and/or resources. The scheme allowed for farming on a small, medium or large scale by granting 99-year leases to its beneficiaries. In reality, Moyo (2004) cited in Zikhali (2010) argues that the Model A2 was riddled with tenure insecurity as the conditions of subletting these farms are not clear. Technically, the tenure insecurity associated with the Model A2 has had an adverse impact on the banking sector's appetite to use these farms as collateral for loans granted to prospective emerging farmers.

\section{Zimbabwe after Land Reform}

Most scholars recognise the role that FTLRP played in the eventual erosion of economic activity in Zimbabwe. Prior to 1999, the largest employer and traditional source of exports and foreign exchange was the commercial farming sector. Over a two-year period, the transfer of 9.5 million hectares of formerly white-owned land to the beneficiaries of the FTLRP was characterized by widely televised cases of violence and chaos. In response to these events, the international community (led by the US, the EU and Australia) condemned the Zimbabwean government's radical FTLRP and implemented a series of targeted sanctions to force change. These 'smart' sanctions targeted approximately 120 senior government officials and associated state companies. These sanctions included the freezing of assets and international travel bans. The idea behind the 'smart' sanctions was to avoid punishing the average citizen for the wrongdoings of a small group of government officials. In theory, 'smart' sanctions should not have the same effect caused by blanket economic sanctions, which impose a ban on the entire country. However, the application of 'smart' sanctions was followed by widespread shortages of basic commodities, record-breaking hyperinflation and unemployment. According to Hanke and Kwok (2009), the month of November 2008 saw inflation at its highest level ever of 79,600,000,000\% per month. This resulted in the abandonment of the Zimbabwe Dollar and the adoption of the United States Dollar and the South African Rand. Luebker (2008) argued that around the same time, unemployment in Zimbabwe was as high as 81\% when he conducted his study in collaboration with the International Labour Office. Once considered the "bread basket" of Africa, the economic turmoil turned the country into a net importer of food. The transport, health, power supply, water and sanitation infrastructure deteriorated to levels never seen before.

A power-sharing government formed in early 2009 curbed the unrelenting economic situation. Since the local currency had been eliminated, the official adoption of a multi-currency regime revived financial intermediation and led to an improved economic outlook. The IMF (2011) estimated that the economy would grow by $3 \%$ in 2012. Starting off a low base, GDP growth in 2009 was 5.9\%, peaking to $9 \%$ in 2010 down to $6 \%$ growth in 2011 (IMF, 2011) driven by strong growth in the mining and agriculture sectors.

\section{The Economic Role of Tobacco in the Zimbabwean Economy}

According to the Food and Agriculture Organisation (FAO)(2003), about 100 countries produce tobacco. However, over $80 \%$ of the world's tobacco is produced in China, India, Brazil, the United States, Turkey, Zimbabwe and Malawi. The report also projected that world tobacco production would reach over 7.1 million tonnes by the year 2010, although tobacco leaf production in developed countries (including the U.S.) would fall.

Table 1: Top Tobacco Producing Nations

\begin{tabular}{|l|c|c|}
\hline Production '000 tonnes & Actual 2000 & Projected 2010 \\
\hline World & 6137.7 & 7160.0 \\
\hline China & 2298.8 & 2972.5 \\
\hline India & 595.4 & 685.4 \\
\hline Brazil & 520.7 & 584.7 \\
\hline USA & 408.2 & 526.8 \\
\hline EU & 314.5 & 300.9 \\
\hline Zimbabwe & 204.9 & $232.8^{*}$ \\
\hline Turkey & 193.9 & 268.8 \\
\hline Indonesia & 166.6 & 119.6 \\
\hline USSR (former area) & 116.8 & 70.0 \\
\hline Malawi & 108.0 & 137.9 \\
\hline
\end{tabular}

*Accurate at time of publication. Estimates have been subsequently revised

Source: FAO (2003): Projections of Tobacco Production, Consumption and Trade to the year 2010, page 40 
Tobacco production in Zimbabwe (formerly Rhodesia) started in the late 1800s. Tobacco production grew steadily over the next three decades until the Rhodesia Tobacco Association (RTA) was formed in 1928. The RTA formalised and boosted the country's tobacco yield. The global demand for tobacco increased exponentially after World War II (19391945). At the time, America's soldiers were receiving free cigarettes and became loyal customers after the war. In Rhodesia, domestic demand for cigarettes was minor, allowing $98 \%$ of tobacco to be exported out of the country. Through the 1980s and 1990s tobacco yield continued to grow. By 2000, Zimbabwe was the sixth biggest producer of tobacco in the world with 204900 tonnes for the year.

However, the government's decision to implement the FTLRP in 2000 had a negative impact on the economy and financial institutions could no longer provide the loans required by the farmers to grow their tobacco. In response to the declining yield seen in the country, the industry introduced a dual marketing system in 2004. Under the dual system, farmers were able to either sell their crop on auction, as they did before, or sell under the new system of contract farming. By 2010 , contract farming accounted for $72 \%$ of tobacco sales due to its unique ability to provide the farmer with inputs in a market with limited access to bank loans.

Food and Agriculture Organisation (FAO) projected that production would reach 232800 tonnes by the year 2010 as indicated by Table 1. with production only reaching 57000 tonnes in 2009. Despite this, there has been a determined effort on the part of all stakeholders (tobacco board, government, farmers, financiers, and agribusiness) to restore the tobacco industry to its former glory. The first milestone was reached in 2010 when production doubled to 114000 tonnes according to The Tobacco Research Board of Zimbabwe (refer to Table 2). The biggest driver of this resurgence was contract farming.

Table 2: Zimbabwe's Tobacco Production Output

\begin{tabular}{|c|c|}
\hline Year & Production ('000 tonnes) \\
\hline 1995 & 198380 \\
\hline 1996 & 208716 \\
\hline 1997 & 215369 \\
\hline 1998 & 260000 \\
\hline 1999 & 193183 \\
\hline 2000 & 237000 \\
\hline 2009 & 57000 \\
\hline 2010 & 114000 \\
\hline
\end{tabular}

Source: The Tobacco Research Board of Zimbabwe, 2010

Tobacco growing is central to Zimbabwe's economy despite the restrictions lobbied by the World Health Organisation (WHO). Francois van der Merwe, the Chief Executive of the Tobacco Institute of Southern Africa (TISA) argues that:

'tobacco plays such a large role employing people (in Africa), seeing that people make a living for themselves and factories employing people and yet of course the industry is being regulated and taxed and severely restricted' (TISA, 2010).

In terms of revenue to farmers in Zimbabwe, the total annual sales have ranged from $\$ 270$ million and $\$ 593$ million from 1990 to date (TIMB, 2010). On the $4^{\text {th }}$ of August 2010, the Tobacco Industry Marketing Board (TIMB) noted that $\$ 318$ million worth of tobacco had been sold. In terms of government revenue, growers and buyers pay a fixed percentage on the value of crop sales. The tax rates had been reduced since 1999 to encourage production. Based on the 2001 tax rates, the FAO calculated that a typical farmer that yields 2500 kilograms per hectare generated $\$ 132$ per hectare in tax revenue $(F A O, 2003)$. Government revenue from tobacco growing is summarised in Table 3 below.

Table 3: Government of Zimbabwe Tobacco Levy

\begin{tabular}{|c|c|c|}
\hline Auction Year & Tax Rate (\%) & Total Revenue (US\$) \\
\hline 1996 & $5+5$ & 43553989 \\
\hline 1997 & $5+5$ & 43236859 \\
\hline 1998 & $5+5$ & 37248464 \\
\hline 1999 & $5+5$ & 33455822 \\
\hline 2000 & $2.5+2.5$ & 18400000 \\
\hline
\end{tabular}

Source: Historical values from ZTA data, 2004 
The International Tobacco Growers Association (ITGA) is a global body that represents 30 million farmers. An Independent Impact Assessment commissioned by the ITGA showed that 3.6 million people in Malawi, Mozambique, Uganda, Zambia and Zimbabwe are dependent on the tobacco growing industry (TISA, 2010). These governments would have to contend with declining GDP, reduced exports, and rising poverty and unemployment if the tobacco industry collapsed (TISA, 2010).

\section{The TIAN ZE Tobacco Company (Private) Limited}

The Chinese cigarette consumption market is the largest in the world and China Tobacco International (a state-owned enterprise) is concentrating on establishing international joint-venture cigarette-making enterprises to meet this demand. One such enterprise is the Tian Ze Tobacco Company (Private) Limited (TZTC), a subsidiary of China Tobacco International that was established in Zimbabwe in 2006. TZTC aims to become the principal agricultural support company strategically located in what was once the largest producer of tobacco in Africa. TZTC's mandate is to supply high quality and sufficient quantity tobacco leaf for China Tobacco International, using the centralised contract farming model. TZTC also strives to provide professional services in addition to a sustainable input scheme that meets the farmer's needs.

\subsection{TIAN ZE'S Footprint Across Zimbabwe}

TZTC is headquartered in the industrial hub of Southerton in Harare the capital city of Zimbabwe. The total number of tobacco farmers contracted to the firm for the year $\mathbf{2 0 1 0}$ was 208. These farmers are predominantly black and are spread across four main designated areas in the three main tobacco-growing provinces of Zimbabwe namely Mashonaland West, Mashonaland Central and Mashonaland East.

For operational purposes, TZTC has four designated areas; these are Mashonaland West, Mashonaland Central, with Mashonaland East being split into two areas namely Mashonaland East North and Mashonaland East South.

Figure 1: The Provinces of Zimbabwe

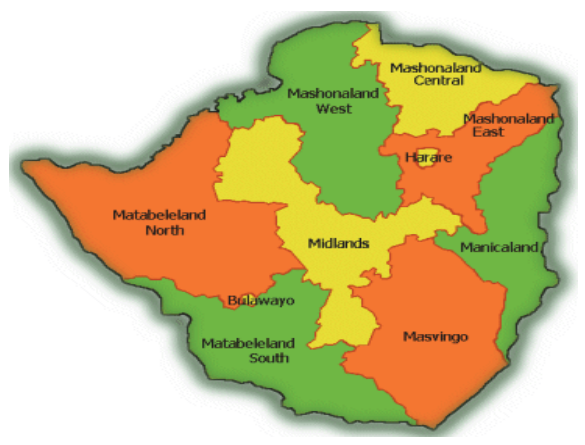

Source: http://www.peterhouse.org/html/peterhouse-maps-directions.html,2012

TZTC has four area managers covering the tobacco growing provinces. The number of farmers each area manager has is tabulated below.

Table 4: Total number of farmers per area

\begin{tabular}{|l|c|}
\hline \multicolumn{1}{|c|}{ Area } & Total number of farmers \\
\hline Mashonaland West & 56 \\
\hline Mashonaland Central & 69 \\
\hline Mashonaland East North & 33 \\
\hline Mashonaland East South & 50 \\
\hline
\end{tabular}

Source: Tian Ze Tobacco Company, 2011 


\title{
7. Contract Farming
}

According to Glover (1987 and 1990), the essence of contract farming is a commitment to the farmer to specify the amount of agricultural produce the agribusiness firm will buy and at what price(see also D'Silva et al. 2009; Da Silva 2005; Shepherd, 2013; FAO, 2013). Pritchard and Connell (2011) argue that contract farming is a set of organisational practices designed by downstream agribusiness firms to manage upstream uncertainty and risk. Typically, the agribusiness firm provides fertilizer, seeds, insecticides, farm machinery and technical advice while the farmer provides land and labour (Glover,1987 and 1990; Porter \& Phillips-Howard, 1997). According to Rural Learning Center(2014:1),

\begin{abstract}
"Contract farming is agricultural production carried out according to an agreement between a buyer and farmers, which establishes conditions for the production and marketing of a farm product or products. Typically, the farmer agrees to provide established quantities of a specific agricultural product, meeting the quality standards and delivery schedule set by the purchaser."
\end{abstract}

It is argued that contract farming is seen as a vehicle of modernisation and provides a way to integrate emerging farmers into export markets and the modern economy (Porter \& Phillips-Howard, 1997). Singh (2002) remarks that agribusiness advocates argue that contract farming leads to higher income and increases employment in less developed regions. Warning and Key (2002) concluded that contract farming created 'positive multiplier effects' for employment and infrastructure for peanut farmers in Senegal. Empirically, Goldsmith (1985) demonstrated a significant increase in rural income after reviewing 12 case studies. He further added that an increase in income was associated with improved productivity. Pritchard and Connell (2011) concluded that contract farming had a positive impact for participants after studying 76 contracted chilli growers in various districts in India. The Gibbon and Jones (2009) analysis of organic coffee farmers in Uganda found that contract farming participation had a positive impact on income.

In these studies, contract farming provided the farmer with the inputs, marketing, technical assistance and finance required to produce his/her crop, the precursor to an increase in earnings. In some instances, banks accepted the contract itself as sufficient collateral to grant a loan (Rebher, 2007). Hill and Ingersent (1982) cited in Singh (2002) suggest that contracts can offer farmers the capital they require to expand their businesses. To the agribusiness firm, contract farming provides greater regularity (as specified by contracts), access to land (without the cost of owning the land) and reduced labour costs (without having to hire its own labour force). The contracts are either written or verbal (Smalley, 2013).

Conversely, the literature suggests that contract farming can be exploitative in nature as agribusiness firms enjoy an unequal bargaining position with farmers(see for example Watts,1994; Little and Watts 1994, Masakure \& Henson, 2005; Sivramkrishna \& Jyotishi, 2008 and Matchaya, 2010) . This criticism stems from the fact that the farmer is bound by the contractual agreement signed with the agribusiness firm. From the perspective of the farmer, this can be likened to a loss of autonomy as the agribusiness firm has indirect control of the land. Clapp (1994) cited in Kirsten and Sartorius (2002) highlighted this by suggesting, "the contracted farmer is sometimes reduced to little more than a hired hand." In their evaluation of contract farming schemes across Africa, Porter and Phillips-Howard (1997) use the phrase "suffering of so many emerging farmers" to describe the unequal bargaining nexus that exists

Glover (1987 and 1990) summarised the other problems encountered by contracted farmers after studying the literature. These problems include unexplained raising of quality standards, poor technical support, in some cases blatant cheating, and late payments.

Similarly, agribusiness firms have been recorded as being 'frustrated' by the resourceful nature of farmers who sell their produce to open markets, if the price is higher than the agreed price (Pandit et al., 2009).

\subsection{Contract Farming Activities}

Prior to joining the TZTC input scheme, the area managers inspect the farm to ascertain whether the farmer has the infrastructure (i.e. tobacco flue curing barns), labour and the technical expertise to grow a successful crop. At the beginning of the planting season, farmers consult their respective area managers with a business plan, which includes a projected seasonal cash flow statement. The cash flow statement is a critical tool in the business plan as this guides how, when and at what stage of the tobacco plant's life cycle funds are released to the farmer. The balance of the business plan includes projected crop yield, labour costs, input requirements and potential areas of development. As a guideline, TZTC allocates input costs of US $\$ 5,000$ per hectare of tobacco.

Once the area manager and TZTC management have approved the business plan, the farmer is contracted to 
grow the tobacco in return for the financing of the inputs, the marketing of resulting crop produced and technical assistance. Typically, TZTC charges an interest rate of 5\% to the emerging farmer, well below the average commercial banks' lending rate of $20-30 \%$.

As a condition of the contract, farmers are obligated to obtain agricultural insurance to protect them against crop damage. The insurance covers against "Acts of God" such as hail or insect damage. It must be highlighted that the insurance does not provide cover against low crop yield due to man made errors or omissions.

The area manager signs off all direct disbursements from TZTC to the farmer. These include the farmer's salary and wages for farm labourers. The costs relating to the other inputs are settled directly with the supplier (i.e. fertilizer, seed, and farm equipment). Purchasing in bulk allows the farmers to obtain most inputs from TZTC at prices that are lower than market prices. Farmers are issued with coupons to obtain diesel for their tractors. At harvest time, the farmer is obligated to transport the cured tobacco to the TZTC warehouse.

Initially, area managers make regular site visits (once or twice a week) to establish protocol with farmers that have newly joined the scheme. The area manager intends to use the frequent visits to reduce asymmetric information by verifying such factors as the number of labourers, tractors and tools versus the figures stated by the farmer.

Nonetheless, area manager site visits are dependent on performance. Farmers who have been a part of the scheme for two or more seasons but are not performing optimally should expect an area manager visit once or twice a week. Farmers who meet their agreed targets require less attention from the area manager who will on average visit once or twice a month. Typically, the area manager's site visit presents an opportunity to revise the farmer's progress report. This includes a reconciliation of the drawdowns on the facility granted at that point in time. Budget overruns are noted for the next month and the shortfall to these is at the farmers account. Budget surpluses are carried over to the following month for the farmer to access when requested. TZTC follows strict quality standards and all sub-standard tobacco is returned to the farmer

\section{Conclusion}

Contract farming seems to have a lot of advantages in the promotion of Agribusiness. What is important is to ensure that farmers are protected from unscrupulous dealers. TZTC has purchase agreements with numerous black commercial tobacco farmers in Zimbabwe. Taking into account the historical legacies that have shaped the country, the objective of this research was to examine the sustainability of contract farming arrangement for emerging black farmers. It can be concluded that contract farming has the potential to promote agricultural productivity and farm income. The model should be extended to emerging farmers who struggle to have access to finance for their productive endeavours.

\section{References}

Anim, F.D.K., Raphala, S.B. \& Mandleni, B. (2008). Contract Farming: A Case of Small Scale Sunflower Farmers in Bojanala District of North West Province. Journal of Agricultural Research, 46(2), 187 - 202.

Baumann, P. (2000). Equity and Efficiency in Contract Farming Schemes: The Experience of Agricultural Three Crops. October 2000. [Online] Available: www.odi.org.uk/ Accessed: 29 August 2012.

Bellemare, M.F. (2010). Agricultural Extension and Imperfect Supervision in Contract Farming: evidence from Madagascar. Agricultural Economics, 41, $507-517$.

Bernstein, A., McCarthy, J., Shepherd, D., de Villiers, R. \& Vegter, I. (2008). Farmers' Voices: Practical perspectives on land reform and agricultural development. The Centre for Development and Enterprise (CDE). Number 9. February 2008. Parktown, Johannesburg. South Africa.

Catelo, M.M.O. \& Costales, A.C. (2008). Contract Farming and Other Market Institutions as Mechanisms for Integrating Smallholder Livestock Producers in the Growth and Development of the Livestock Sector in Developing Countries. 2009. [Online] Available: www.fao.org/ag/ppli.html Accessed: 29 August 2012.

D'Silva, J.L., Shaffril, H.A.M., Uli, J. \& Samah, B.A. (2009). A Review of Contract Farming and Factors that Impinge Youths' Acceptance to Contract Farming. European Journal of Social Sciences, 11(2), $328-338$.

Da Silva, C.A. (2005). The Growing Role of Contract Farming in Agri-Food Systems Development: Drivers, Theory and Practice. July 2005. [Online] Available: www.fao.org Accessed: 7 September 2011.

De Villiers, B. (2008). Land Reform - A Commentary. Konrad Adenauer Stiftung Policy Paper. Issue No 4. January 2008. Dunkeld, Johanneburg. South Africa.

FAO . (2013). Contract farming for inclusive market access. FAO. Rome

Food and Agriculture Organisation (FAO). (2003). Projections of Tobacco Production Consumption and Trade to the year 2010 pg 40.[Online] http://www.fao.org Accessed: 21 August 2012.

Gibbon, P., Bolwig, S. \& Jones, S. (2009). The Economics of Smallholder Organic Contract Farming in Tropical Africa. World 
Development, 37(6), 1094 - 1104.

Glover, D. (1990). Contract Farming and Outgrower schemes in East and Southern Africa. Journal of Agricultural Economics, 41(2), 303 $-315$.

Glover, D.J. (1987). Increasing the Benefits to Smallholders from Contract Farming: Problems for Farmers' Organizations and Policy Makers. World Development, 15(4) 441 - 448.

Goldsmith, A. (1985). The Private Sector and Rural Development: Can Agribusiness Help the Small Farmer? World Development, 13(10/11), $1125-1138$.

Hanke, S. H. \&Kwok, A. K. F. (2009). On the Measurement of Zimbabwe's Hyperinflation. Cato Journal, 29(2), 353 - 364.

International Finance Corporation (IFC). (2010). Regional Agriculture and Food Security Forum 2010. Outcomes Report. December 2010. Illovo, Johannesburg. South Africa.

International Monetary Fund. (2011). Regional Economic Outlook 2011: Sub-Saharan Africa. [Online] Available: http://www.imf.org Accessed: 21 August 2012.

Kirsten, J. \& Sartorius, K. (2002). Linking Agribusiness and Small-scale Farmers in Developing Countries: is there a new role for contract farming? Development Southern Africa, 19(4), 503 - 530.

Little, P. D. \& Watts, M. (1994). Living under Contract. Madison. United States of America. University of Wisconsin Press

Luebker, M. (2008). Employment, Unemployment and Informality in Zimbabwe: Concepts and Data for Coherent Policy-Making. International Labour Office, Issues Paper No 32. Geneva, Switzerland.

Masakure, O. \& Henson, S. (2005). Why Do Small-Scale Producers Choose to Produce under Contract? Lessons from Nontraditional Vegetable Exports from Zimbabwe. World Development, 33(10), 1721-1733.

Matchaya, G.C. (2010). Cooperative Patronage: The National Smallholder Farmers' Association of Malawi in Kasungu District. Development Southern Africa, 27(3), 397 - 412.

Pandit, A., Pandey, N.K., Rana, R.K. \& Lal, B. (2009). An Empirical Study of Gains from Potato Contract Farming. Indian Journal of Agricultural Economics, 64(3), 497 - 508.

Porter, G.\& Phillips-Howard, K. (1997). Comparing Contracts: An Evaluation of Contract Schemes in Africa. World Development, 25(2), $227-238$.

Pritchard, B. \& Connell, J. (2011). Contract Farming and the Remaking of Agrarian Landscapes: Insights from South India's Chilli Belt. Singapore Journal of Tropical Geography, 32, 236 - 252.

Prowse, M. (2012). Contract Farming in Developing Countries - A Review. February 2012. [Online] Available: www.recherche.afd.fr Accessed: 29 August 2012.

Rehber, E. (2007). Contract Farming: Theory and Practice. London. UK.ICFAI Books.

Rural Learning Center . (2014). Contract farming. [Online] Available: http://www.ruralfinance.org/library/business-supportservices/contract-farming/en/?no_cache=1 (August 5, 2014).

Sartorius, K. \& Kirsten, J. (2007). A Framework to Facilitate Institutional Arrangements for Smallholder Supply in Developing Countries: An Agribusiness Perspective. Food Policy, 32, 640 - 655.

Shaw, W. H. (2003). They Stole Our Land: debating the expropriation of white farms in Zimbabwe. Journal of Modern African Studies, $41(1), 75-89$.

Shoja Rani, B.N. (2007). Globalisation and Contract Farming in India - Advantages and Problems. [Online] Available: www.iimahd.ernet.in/ Accessed: 29 August 2012.

Singh, S. (2002). Contracting Out Solutions: Political Economy of Contract Farming in the Indian Punjab. World Development, 30(9), $1621-1638$.

Sivramkrishna, S. \& Jyotishi, A. (2008). Monopsonistic Exploitation in Contract Farming: Articulating a Strategy For Grower Cooperation. Journal of International Development, 20. 280 - 296.

Smalley R. (2013). Plantations, Contract Farming and Commercial Farming Areas in Africa: A Comparative Review. Land and Agricultural Commercialisation in Africa(LACA) project, Working paper 055. Institute for Poverty, land and Agricultural Studies(PLAAS). http://www.ruralfinance.org/library/business-support-services/contract-farming/en/?no_cache=1.

Tobacco Industry and Marketing Board of Zimbabwe. (2010). A Snapshot into Zimbabwe's Tobacco Industry. [Online] Available: http://www.timb.co.zw (September 13, 2011).

Tobacco Industry Marketing Board (TIMB). (2010). [Online] Available: www.timb.co.zW. (August 6, 2014).

Tobacco Institute of Southern Africa (TISA). (2010). Summer Edition Newsletter December 2010. [Online] Available: http://www.tobaccosa. co.za . (September 13, 2011).

Waeterloos, E. \& Rutherford, B. (2004). Land Reform in Zimbabwe: Challenges and Opportunities for Poverty Reduction Among Commercial Farm Workers. World Development, 32(3), 537 - 553.

Warning, M. \& Key, N. (2002). The Social Performance and Distributional Consequences of Contract Farming: An Equilibrium Analysis of the Arachide de Bouche Program in Senegal. World Development, 30(2), 255 - 263.

Watts, M. (1994). Life under contract: contract farming, agrarian restructuring and flexible accumulation. Living under contract. Madison. United States of America. University of Wisconsin Press.

Zikhali, P. (2010). Fast Track Land Reform Programme, Tenure Security and Investment in Soil Conservation: Micro-evidence from Mazowe District in Zimbabwe. Natural Resources Forum, 34, 124 - 139. 